\title{
Možnosti turistiky vozíčkářů v Beskydech
}

\section{Tourism opportunities for wheelchair users in Beskydy Mountains}

\author{
Martina Korhelíková ${ }^{1,2}$ \\ ${ }^{1}$ Rehabilitační ústav Hrabyně, Hrabyně, Česká republika \\ ${ }^{2}$ Fakulta tělesné kultury, Univerzita Palackého, Olomouc, \\ Česká republika
}

\begin{abstract}
Abstrakt:
Práce „Možnosti turistiky vozičkář̃ v Beskydech“ se zaměřuje na monitorování pohoři Beskyd z hlediska př́stupnosti turistických tras pro vozíčkáre. Záměrem bylo vytvořit soubor turistických tras sjizdných pro vozíčkáre a prostřednictvím organizace KAZUIST s. $r$. o. tyto informace poskytnout široké veřejnosti, predevším vozičkárưm. Výsledkem je zveřejnění monitorovaných tras na internetu prostřednictvím webu jedemetaky.cz.
\end{abstract}

\section{Abstract:}

The thesis "Tourism opportunities for wheelchair users in Beskydy Mountains" focuses on monitoring Beskydy mountains in terms of accessibility for the disabled tourist paths. The intention was to create a set of hiking trails passable for wheelchair users and provide this information through organizations KAZUIST s. r. o. to the general public especially wheelchair users. The result is a publication of the monitored routes to the Internet via the Web jedemetaky.cz. 
Kličová slova: rekreace, pohyb, turistika vozičkárùi, sport vozičkárưu, aplikované pohybové aktivity.

Key words: recreation, movement, tourists of wheelchair users, sport of wheelchair users, applied physical activities.

\section{ÚVOD}

Mobilita zvaná také hybnost znamená všechny pohybové funkce vykonávané kosterním svalstvem, přemístění těla $\mathrm{v}$ prostoru, pracovní výkon. Tyto pohyby jsou ř́zeny z motorické oblasti mozku (Renotiérová, 2006). Mobilita jedinců s tělesným postižením $z$ velké části ovlivňuje kvalitu jejich života, a tudíž je základním předpokladem jejich úspěšné sociální integrace (Vítková, 2006). „Protože pohyb je, byl a vždy bude součástí života každého jedince, a pokud dojde k jeho omezení, at'v důsledku jakéhokoliv úrazu, nebo jiné přičiny, tak je třeba poukázat, že jakákoliv alternativní pohybová složka cvičení přináši tu maximální možnou míru zlepšení sebeobslužnosti, soběstačnosti a to má za následek zvyšování celkového profilu kvality života "(Čichoň, 2005, p. 3). Pohyb je zcela jistě člověku zdraví prospěšný a má pro něj pozitivní význam. Pro jedince s pohybovým postižením má význam také kompenzační ve smyslu vyrovnávání nerovnováhy $\mathrm{v}$ organismu a jeho funkcí v důsledku vrozené či získané poruchy a edukační či reedukační při nabývání nebo obnovování pohybové dovednosti. Je zdůrazňován pohyb nejen jako činitel upevňující zdravotní stav a prevenci, ale také tělesnou zdatnost. Je chápán jako koordinační faktor tělesného, psychického a sociálního vývoje. Zlepšuje kondici a aktuální psychický stav, vytvárí nebo obnovuje životní perspektivy jedinců se zdravotním postižením. Při pěstování pohybu dochází $\mathrm{k}$ rozvoji motorických kompetencí uplatnitelných $\mathrm{v}$ běžném životě, které přispívají ke zvýšení kvality i kvantity pohybových vzorců, upevňování sebevědomí, rozvíjení sociální dovednosti a empatie (Ješina, Hamř́k et al., 2011). Dle Rollanda (1997) pohybová aktivita souvisí s celkovým rozvojem lidské osobnosti a její celkové kognitivní 
kapacity. Pohybová aktivita má velký vliv na celkový psychický stav jedince. Díky fyzické náročnosti je trénovaná vůle, psychická vytrvalost, houževnatost, cílevědomost, rozhodnost, odvaha, odolnost proti stresu apod. (Hodaň, 2005). Hrouda a Rybová (2010) uvádí, že překonáváním a zdoláváním jistých sportovních cílů posouvají osoby se zdravotním postižením své každodenní překážky do ústraní, stávají se běžně zdolatelnými bez jakýchkoli problémů. Dokazuje to např́klad výstup dvou vozíčkářů na nejvyšší vrchol České republiky Sněžku. Pan Dušek říká: „Pro postižené jsou podobné akce ohromnou výzvou. Obstojí-li na horských cestách, je pro ně mnohem jednodušší překonávat překážky ve městech, například obrubníky nebo jiné potíže." V současnosti jsou opomíjené veškeré pohybové aktivity všemi věkovými skupinami lidí. Narůstá procento lidí s neinfekčním onemocněním $\mathrm{v}$ důsledku nezdravé stravy a nedostatečné pohybové aktivity. Je potřeba, aby bylo na tuto skutečnost poukázáno a aby si lidé uvědomili, že pohyb a pobyt v př́rodě je pro člověka velmi důležitý. Snad každý z nás po procházce nebo túře prožívá pocity zdraví, pohody a duševního obohacení. Stejně tak pro člověka s tělesným postižením je pobyt na čerstvém vzduchu v prírodě neméně důležitý a obohacující. Vhodnou variantou, jak trávit čas v přírodě a pritom se nejen hýbat, ale i poznávat nové věci a získávat nové zkušenosti, je turistika. Pro lidi s tělesným postižením se nabízí turistika vozíčkářů, která vyžaduje dodržení určitých kritérií pro přístupnost a sjízdnost dané trasy. Dá se předpokládat, že v každé turistické oblasti se skrývají trasy sjízdné pro vozíčkáře, jen je potřeba je najít a ukázat. Je důležité vhodné trasy uveřejnit a nabídnout daným klientům. Mnoho z nich ani netuší, kam až by se mohli dostat a obohatit tak svoji fyzickou i psychickou stránku života a přispět tak ke svému zdraví. Výhodou turistiky na vozíku je, že k ní není potřeba žádného speciálního a drahého vybavení a lze ji provozovat v každém věku. Turistiku lze provozovat s rodinou, $\mathrm{s}$ kamarádem, př́telem nebo samostatně. Cílem veškerých pohybových aktivit, tudíž i turistiky tělesně postižených, by měla být co největší možná samostatnost, psychická stabilita a fyzická zdatnost. Vymanit osoby s handicapem z izolace. Snažit se vytvářet pozitivní mezi- 
lidské vztahy a tím lidi s postižením zařazovat do běžného života. Dle mého názoru turistika vozíčkářů splňuje všechny zmíněné faktory, a tak je vhodnou volbou jak zpestřit nebo obohatit aktivní způsob života lidí s tělesným postižením.

\section{METODIKA}

V první fázi monitorování byl proveden návrh 30 sledovaných tras, z kterého byl proveden výběr 13 monitorovaných tras. Metoda pozorování a měření se uplatňovala př́mo v terénu. Hodnocení bylo zaměřeno na kvalitu povrchu $\mathrm{z}$ hlediska materiálů a stavu. Byl hodnocen materiál povrchu, kvalita povrchu a prítomnost defektů či terénních nerovností, které by bránily sjízdnosti pro vozíčkáře.

Povolena hodnota příčného sklonu, byla $2 \%$. Trasy, které překračují tuto hodnotu, můžeme považovat za nebezpečné z hlediska jízdy na vozíku. Podélný sklon byl hodnocen slovním vyjádřením ve smyslu rovinatý, mírně zvlněný, zvlněný, kopcovitý, mírné, prudší, prudké, krátké, dlouhé stoupání nebo klesání apod. Bezpečnost trasy je ovlivněna slunečním svitem. Bylo popisováno, zda trasa vede chráněným lesním porostem, úbočími údolí nebo zda celá trasa vede lesem, dále bylo posuzováno, zda je trasa na nebezpečných úsecích lemována obrubníky, zábradlím nebo madly. Z hlediska charakteru povrchu byly přesně popisovány překážky vyskytující se na trasách, které by mohly omezovat uživatele vozíků při jízdě. Byly měřené přesné hodnoty výškových rozdílů. Za překážky byly rovněž považovány díry, závory, svodnice vody, otvory, kameny, kořeny atd., které nelze žádným způsobem objet nebo se jim vyhnout. Také bylo hodnoceno, zda je trasa osvětlená. Z hlediska komfortu a pohodlí vozíčkářů při zdolávání trasy byla hodnocena přítomnost, umístění a rozvržení mobiliářů, zdrojů pitné vody, odpadkových košů a bezbariérových WC podél trasy. Na trase bylo hodnoceno značení informačními a orientačními prvky, které poukazují na směr trasy nebo ukazují cestu k cíli. Informační panely by měly obsahovat jasné a srozumitelné informace a měly by být dobře čitelné, proto musí být zachováno jejich určité umístění. V rámci hodnocení byla posuzována 
i okolní infrastruktura. Zda okolí trasy nabízí možnost bezbariérového občerstvení, kiosku nebo restaurace. Také jestli se v okolí nacházejí zařízení v podobě různých atrakcí, jako jsou např̀. vyhlídky, rozhledny, mola, dětské hřiště a rovněž byla hodnocena jejich bezbariérovost. Hodnocení také obsahovalo zjištění skutečnosti, zda je možné se o trase předem dozvědět a dočíst se podrobnější informace o trase, at' už v podobě tištěných informačních letáků, plánků, publikací nebo může klient informace získat $\mathrm{v}$ elektronické podobě z webových stránek nebo z audiovizuální prezentace. Součástí formuláře bylo zjišt'ování, zda je trasa obsluhována personálem a jestli je personál proškolen a připraven poskytovat kvalitní služby osobám se specifickými potřebami. Důležitou informací pro klienta je možnost využití různých služeb na trase, jako je možnost zapůjčení vozíků nebo motorové vozítka, možnost sjednání asistenční služby nebo průvodce. Neméně důležité je i zaznamenání do jaké míry je trasa pokrytá signálem a uvedení místa nejbližší nemocnice nebo lékařského zařízení, př́ípadně poskytnutí kontaktu na horskou službu, která v dané oblasti působí.

Mimo samotné trasy byl monitoring zaměřen na přístupnost trasy ve smyslu možnosti parkování, prŕistupového chodníků k trase, vstupu na trasu s př́slušenstvím, hygienickým zařízením, pokladnou, restaurací a podobně. Parkoviště bylo posuzováno z hlediska kapacity stání osobních aut, lokalizací parkoviště vůči začátku trasy, osvětlení parkoviště, materiálu povrchu parkoviště a z hlediska posouzení nerovností, defektů nebo výmolů bránících sjízdnosti vozíků. Dále na parkovišti bylo monitorováno, zda na něm jsou vyhrazená parkovací místa pro vozidla přepravující osoby tělesně postižené, jaká je kapacita těchto parkovacích míst, jak je toto parkovací místo vyznačené a kde se nachází. Také bylo zjišt’ováno, zda je možné prrípadně zastavit přímo u vchodu na danou trasu. Př́stupovým chodníkem je myšlena cesta od parkoviště k začátku trasy a byl hodnocen stejným způsoben jako samotná trasa. 


\section{VÝSLEDKY}

Obtížnost tras byla hodnocena dle kritérií Klubu českých turistů. Trasy byly rozděleny do tří skupin dle obtížnosti vzestupně modrá, červená a černá. Pro modrou obtížnost nesplňovala kritéria žádná trasa. Pět tras bylo označených jako červené, které zdatný vozíčkář většinou sám zvládne. Pět tras bylo označeno jako červené, které vozíčkář zvládne pouze v doprovodu, proto je částečně vhodná. Nejčastěji byla trasa označena jako černá z důvodu úseku s prudkým stoupáním nebo úseku s obtížným povrchem, který vyžaduje asistenci. Tři trasy nesplňovaly žádné z těchto kritérií, byly vozíčkáři nesjízdné, proto byly označeny pro vozíčkáře jako nevhodné. Z hlediska povrchu bylo monitorováno šest tras s asfaltovým povrchem, můžeme je pokládat jako zcela vhodné pro jízdu na vozíku. Šest tras tvoří kombinace asfalt a jiný povrch typu lesní cesta nebo štěrkový povrch, tudíž se tyto trasy stávají částečně vhodné pro jízdu na vozíku. Většinou je sjízdná jen část trasy nebo je úsek s obtížnějším povrchem sjízdný jen s asistencí, př́ípadně se dá tomuto úseku vyhnout jinou trasou. Jedna trasa byla označena jako trasa s povrchem lesní chodník, tudíž nesjízdná pro vozíčkáře. Parkoviště s vyhrazeným stáním pro lidi s tělesným postižením obsahovaly jen dvě trasy. Většina tras parkoviště měla, ale bez vyznačeného stání pro osoby s tělesným postižením. Na dvou trasách se nevyskytuje žádné parkoviště. Od parkoviště k trase se jen ojediněle vyskytoval přístupový chodník. U většiny tras je možno jít z parkoviště přímo na trasu. Ve dvou prrípadech vedl př́istupový chodník po silnici bez dopravního provozu a dvou případech po asfaltovém chodníku. Zabezpečení bezbariérovým hygienickým zařízením na trase je velmi podstatný faktor, díky kterému se může stát trasa pro vozíčkáře neakceptovatelná. V hodnocení pět tras mělo na trase nebo ve svém blízkém okolí bezbariérové WC. Na pěti trasách se vyskytovala pouze WC bariérové a 3 trasy byly bez jakéhokoli hygienického zařízení. Zabezpečení trasy bezbariérovými lavičkami či posezeními bylo relativně uspokojivé. Z třinácti monitorovaných tras mělo sedm tras lavičky či posezení bezbariérové. Dvě trasy měly lavičky nepřístupné pro vozíčkáře a bohužel čtyři trasy neměly lavičky nebo odpočinková zařízení žádné. Pouze 
na třech trasách měl vozíčkář možnost občerstvit se v bezbariérovém restauračním či občerstvovacím zařízení. Na sedmi trasách k tomu, aby se občerstvil, potřebuje doprovod, protože občerstvovací zařízení jsou bariérového typu a na třech trasách si musí vozíčkář vystačit s vlastními zdroji. Žádné občerstvovací zařízení se na těchto trasách nevyskytují. Pokud chce vozíčkář dopředu získat informace o trase, což je pro něj podstatné, nejlepší variantou je internetový zdroj, kde získá informace o šesti trasách, z toho informace o dvou trasách může získat i v tištěné podobě formou letáků nebo informačních brožur. O sedmi trasách informace vedeny nejsou.

Z monitorovaných třinácti tras byly na základě výše popsané metodiky hodnoceny jako vhodné trasy: trasa Bílá (obr. 1), trasa z žst. Čeladná do žst. Kunčice pod Ondřejníkem, trasa Šance, trasa Pod Stolovou a trasa Údolím Černé. Tyto trasy jsou zdatným vozíčkářem sjízdné bez asistence. Trasy Naučné chodníčky v Podbeskydí, Hradní Vrch, Grůn̆, z Kunčic pod Ondřejníkem - Na Pekliskách, Radegast bych označila jako částečné vhodné a to $\mathrm{z}$ důvodů nutné asistenci při zdolávání trasy nebo nutností vyhnout se určitému úseku po jiné trase. Po vyznačení by se některé trasy obtížnosti částečně vhodné, mohly stát vhodnými a sjízdnými pro velký počet vozíčkářù. Tři trasy a to trasa Kamenec, trasa Lašské naučná stezka a Čertův Mlýn jsou pro vozíčkáře nesjízdné. Ve všech třech prŕípadech jsou trasy nesjízdné i s asistencí z důvodů kvality povrchu na většinovém úseku případně po celé délce trasy a není zde možnost vyhnout se tomuto úseku.

V lokalitě Beskyd se nacházejí také vozíčkáři sjízdné trasy mimo turistické a cykloturistické značení, které by se po zmonitorování a vyznačení mohly stát trasami vhodnými pro turistiku vozíčkářù.

Při zpracování byla navázána spolupráce s organizací Kazuist s. r. o. a výsledky práce byly použity při zpracování projektu Cestovní ruch bez bariér. 


\section{ZÁVĚR}

V současnosti se v pohoří Beskyd nenacházejí značené trasy pro vozíčkáře. Z monitorování vyplývá, že Beskydy jsou vhodnou lokalitou pro turistiku vozíčkářu. Pohoří Beskyd je typické př́itomností velkého množství asfaltových tras bez silničního provozu, které jsou vhodné pro turistiku vozíčkářù, bohužel zde chybí zabezpečení typu bezbariérových WC, vhodných parkovišt', bezbariérových restauračních zařízení či občerstvovacích zařízení, které by vozíčkáři výlet usnadnily nebo zpřrijemnily. Doplněním těchto nedostatků by se lokalita Beskydy mohla stát vhodnou turistickou oblastí pro trávení volného času vozíčkářu.

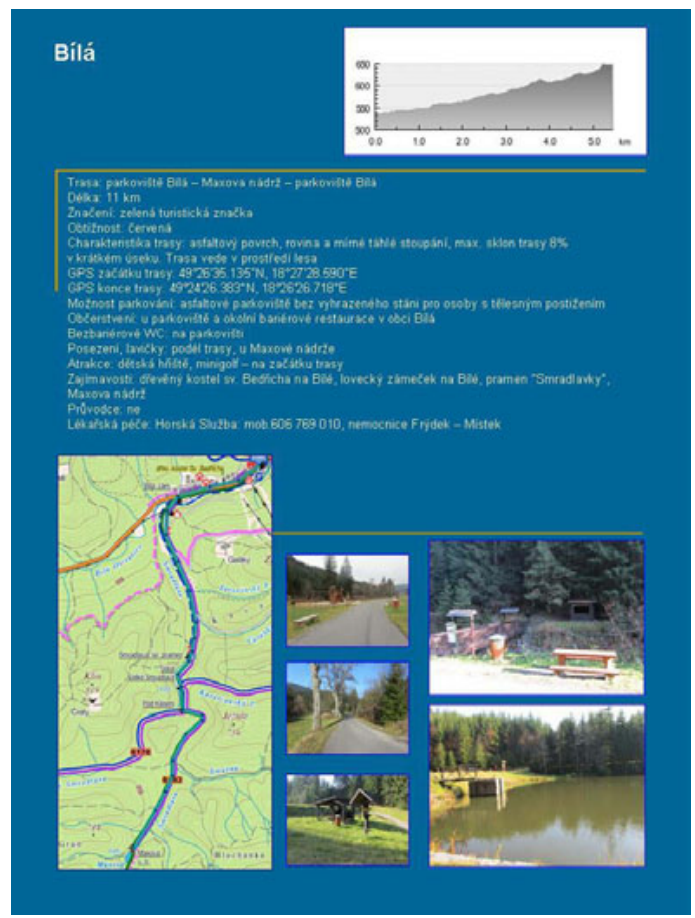

Obr. 1: Grafické zpracování vybraného výletu 


\section{LITERATURA}

Čichoň, R., \& Potměšil, J. (2005). Sport a sportovní př́prava zdravotně postižených. Praha: NK UK.

Hodaň, B., \& Dohnal, T., (2005). Rekreologie. Olomouc: Hanex.

Hrouda, T., \& Rybová, L., (2010). Sport v životní dráze člověka s tělesným postižením. Aplikované pohybové aktivity v teorii a praxi, 1, $56-61$.

Ješina, O., \& Hamř́k, Z. et al. (2011). Podpora aplikovaných pohybových aktivit $v$ kontextu.

volného času. Olomouc: Univerzita Palackého v Olomouci.

Rénotierová, M., \& Ludíková, L., et al. (2006). Speciální pedagogika.

Olomouc: Univerzita Palackého v Olomouci.

Vítková, M. (2006). Somatopedické aspekty. Brno: Paido.

\section{KONTAKT:}

Bc. Martina Korhelíková, martina@korhelik.cz 